\title{
In-situ immobilization of lead using different source of phosphate amendments for the organic production of misai kucing (Orthosiphon stamineus)
}

\author{
Khairun Naim Mulana, Che Fauziah Ishak and Rosenani Abu Bakar \\ Department of Land Management, Faculty of Agriculture, University Putra Malaysia(UPM), 43400,Serdang, Selangor
}

\begin{abstract}
Sustainable organic herbal production requires utilization of bio-waste materials as plant nutrient sources due to its economical aspect and would ensure continuous productivity. The usage of organic wastes in organic farming system (OFS) as fertilizers and soil amendments should be monitored as the accumulation of heavy metals has been reported in several studies. Glasshouse study has been conducted to assess the effectiveness of Pb immobilization due to chicken manure application using different sources of phosphate materials; bone meal (BM), Egyptian rock phosphate (ERP) and triple super phosphate (TSP). From the fractionation of glasshouse study, the percentage of exchangeable fraction of $\mathrm{Pb}$ was reduced with application of P-amendments with the highest of $20.2 \%$ of reduction recorded for 2 t/ha application of TSP. This is followed by reduction in exchangeable fraction for others treatments: 2 t/ha of BM (4.1\%), 4 t/ha of BM (5.1\%), 1 t/ha of ERP (8.1\%) and 2 t/ha of ERP at 17.6\%. These treatments were recorded as being able to stabilize the $\mathrm{Pb}$ as indicated in the percentage reduction of phytoavailable pools into $a$ more stable form of residual pool.
\end{abstract}

Keywords: soil amendments, Egyptian phosphate rock, bone meal, sequential extraction study

\section{Introduction}

Food safety and environmental concerns have gained attention among consumers recently which results in increasing demands of organic farming produce over those of conventional farming. Agronomic practices, such as application of soil amendment and organic fertilizer (types and rates) for organic production of herbs on Malaysian soils have not been well investigated. These practices should be reviewed due to potential of heavy metals accumulation in the herbal produce. Safety assurances of organic herbs products should be monitored along with the enhancement of biomass yield. Chicken manure and organic fertilizers might contribute to higher trace metals uptake in plant tissues particularly for lead. Businelli et al. (2009) indicated animal manure or compost spreading induces an increase in $\mathrm{Cu}, \mathrm{Zn}$ and $\mathrm{Pb}$ contents in the receiving soils. Apparently, Malaysian soils is dominated by Ultisols and Oxisols having low fertility status in which addition of organic amendments such as animal manure, compost and biochar is a must, not only to provide nutrients but also prevent soil erosion, improve soil physical, chemical and biological properties, and protect crops from pathogens (Leroy et al. 2007). Since the nitrogen sources in OFS is usually low, the rates of application are higher compared to chemical fertilizers. Thus, there is potential of heavy metals accumulation in amended soil and consequently in organic produce. Other than agricultural inputs, the source of lead contaminants can be contributed by industrial by-products, urban wastes and automobile gaseous emission (Pallavi and Rama, 2005).

In-situ immobilization is application of soil additives to modify the physico-chemical properties of the contaminating heavy metals combined with the development of biological communities and plants for further metal immobilization in the soil system (Vangronsveld et al. 1995). This method was shown to be a very promising alternative remediation method based on risk reduction, time and cost effectiveness. There are few reports related to copper, zinc and lead accumulations in $O$. stamineus. Abdu et al., (2011) concluded that $O$. stamineus can be a potential phytoremediator for $\mathrm{Pb}$ and $\mathrm{Zn}$, whilst Manan et al., (2015) indicated that $O$. stamineus acts as a moderate accumulator for $\mathrm{Zn}, \mathrm{Cu}$ and $\mathrm{Pb}$. However, zinc and copper are essential for both plants and human, which unlike lead, possess threat even at minimum amounts. Thus, a method of in situ immobilization of lead using phosphate based materials can be selected to reduce the $\mathrm{Pb}$ concentration in this crop. In selecting the most appropriate soil remediation methods, it is of paramount importance to consider the characteristics of the soil and the contaminants (Lestan et al. 2008). Application of apatite as amendment appears to be a promising soil additive for immobilizing metals in polluted soils (Soltan et al. 2012). Its effectiveness has been reported in several studies to reduce $\mathrm{Pb}$ uptake by plants (Cotter-Howells and Caporn 1996; Laperche et al. 1997; Hettiarachchi et al. 2000). This was

*Email: naimmulana@yahoo.com

C 2017, Soil Science Society of Pakistan (http://www.sss-pakistan.org) 
investigated in the study of $O$. stamineus using three sources of phosphorus; bone meal, Egyptian rock phosphate and triple super phosphate. Therefore, the objective of this study was to assess the effectiveness of $\mathrm{Pb}$ immobilization due to chicken manure application using different sources of phosphate materials; bone meal (BM), Egyptian rock phosphate (ERP) and triple super phosphate (TSP).

\section{Materials and Methods}

The growing media was mixed with treatments: control, Egyptian rock phosphate with 2 rates of application of 1 and $2 \mathrm{t} / \mathrm{ha}$, bone meal with 2 rates of application $2 \mathrm{t} / \mathrm{ha}$ and $4 \mathrm{t} / \mathrm{ha}$ along with $2 \mathrm{t} / \mathrm{ha}$ of triple super phosphate as a comparison for reactive type phosphate rock. $10 \mathrm{t} / \mathrm{ha}$ of chicken manure were applied with said treatments as source
Cunnliffe, 1985). Method of Tessier et al. (1979) was selected for the fractionation study. The fractions determined were; (1) exchangeable, (2) carbonates, (3) Fe and Mn oxides, (4) organic matter, and (5) residual. The plant transfer factor (TF) was calculated as follows; $T F=$ (concentration in plant/ concentration in soil), where its represent the metal concentration in extracts of plants and soils on dry weight basis, accordingly.

Trace metals $(\mathrm{Pb}, \mathrm{Cu}$ and $\mathrm{Zn})$ concentration were determined by the graphite furnace atomic absorption spectrophotometer (Perkin-Elmer) accordingly. Analysis of statistical data was carried out using SAS statistical package 9.4 (SAS Institute Inc., Cary, NC, USA). When the ANOVA for interaction parameters was significant, means separation was carried out using HSD-test. All graphs were

Table 1: Selected chemical properties of soil, chicken manure and phosphorus materials

\begin{tabular}{lccccc}
\hline Parameter & $\begin{array}{c}\text { Top } \\
\text { Soil }\end{array}$ & $\begin{array}{c}\text { Chicken } \\
\text { Manure }\end{array}$ & $\begin{array}{c}\text { Egyptian Rock } \\
\text { Phosphate }\end{array}$ & $\begin{array}{c}\text { Bone } \\
\text { Meal }\end{array}$ & $\begin{array}{c}\text { Triple Super } \\
\text { Phosphate }\end{array}$ \\
\hline $\mathrm{pH}$ & 4.12 & 9.2 & 7.27 & 6.94 & 2.59 \\
Total C $(\%)$ & 2.24 & 14.4 & 1.16 & 18.87 & 0.13 \\
Total N $(\%)$ & 0.19 & 1.09 & 0.05 & 4.08 & 0.06 \\
C:N Ratio & 11.79 & 13.21 & 23.20 & 4.63 & 2.17 \\
Moisture Content $(\%)$ & 2.80 & 16.5 & 0.40 & 4.40 & 0.20 \\
Available P (mg/kg) & 14.58 & nd & nd & nd & nd \\
Exch.K(cmol+/kg) & 0.42 & nd & nd & nd & nd \\
Exch.Ca(cmol+/kg) & 2.37 & nd & nd & nd & nd \\
Exch.Mg(cmol+/kg) & 0.23 & nd & nd & nd & nd \\
Total P $(\%)$ & nd* & 2.01 & 9.40 & 1.73 & 84.00 \\
Total K $(\%)$ & nd & 1.22 & 0.15 & 0.05 & 1.58 \\
Total Ca $(\%)$ & nd & 4.47 & 2.88 & 2.98 & 0.50 \\
Total Mg $(\%)$ & nd & 0.46 & 0.20 & 0.13 & 0.22 \\
Cu $(\mathrm{mg} / \mathrm{kg})$ & 15.59 & 88.13 & 18.5 & 6.87 & 51.47 \\
$\mathrm{Zn}(\mathrm{mg} / \mathrm{kg})$ & 28.71 & 477.09 & 125.00 & 130.50 & 319.40 \\
$\mathrm{~Pb}(\mathrm{mg} / \mathrm{kg})$ & 14.01 & 37.76 & 55.00 & 37.60 & 18.79 \\
As $(\mathrm{mg} / \mathrm{kg})$ & bld* & 13.49 & 6.44 & bld & 32.00 \\
$\mathrm{Cd}(\mathrm{mg} / \mathrm{kg})$ & 0.06 & 0.31 & 2.14 & 0.1 & 119.00 \\
$\mathrm{P} \mathrm{water} \mathrm{soluble}(\%)$ & nd & nd & 0.02 & 0.01 & 1.93 \\
$\mathrm{P}$ ammonium citrate soluble $(\%)$ & nd & nd & 0.80 & 1.23 & 0.92 \\
\hline
\end{tabular}

bld= below limit of detection, $n d=$ not determined

of heavy metals as determined by incubation study. The characterization for soil, organic materials and Pamendments used are presented in Table. 1. The soil were air-dried after 8 weeks of incubation and then ground to pass through a $2-\mathrm{mm}$ sieve prior to use. Soil analyses were conducted as follow; soil $\mathrm{pH}$ and $\mathrm{pH}$ of organic and $\mathrm{P}$ amendments (soil:water,1:2.5), Available phosphorus (Bray and Kurtz No. 2), nutrients contents (N, P, K, Ca and Mg) and trace metals contents $(\mathrm{Cu}, \mathrm{Zn}, \mathrm{Pb}, \mathrm{As}$ and $\mathrm{Cd})$ were extracted using aqua-regia extractant (McGrath and plotted using Microsoft Excel 2013 and Sigma Plot software 12.0 version (Systat Software, San Jose, CA). The correlation analyses were conducted to measure the degree of relationship between parameters.

\section{Results and Discussion}

\section{Characterization}

Table 1 shows the chemical characteristics of soil, chicken manure, Egyptian rock phosphate, triple super 
phosphate and bone meal used in this study. The solubility of $\mathrm{P}$ amendments dictates their effectiveness in $\mathrm{Pb}$ immobilization (Soltan et al. 2012). The solubility of phosphate materials were determined using; 1) water soluble $\mathrm{P}$ and 2$)$ neutral ammonium citrate soluble $\mathrm{P}(\mathrm{pH}$ 7). The results indicate that TSP have higher percentage of water soluble $\mathrm{P}$ at $1.93 \%$ compared to ERP and $\mathrm{BM}$ at $0.02 \%$ and $0.01 \%$, respectively. On the other hand, the ammonium citrate soluble $\mathrm{P}(\mathrm{pH} 7)$, indicates higher $\mathrm{P}$ solubility at $1.23 \%$ in BM followed by TSP at 0.92 and $0.80 \%$ in ERP. The total solubility of $\mathrm{P}$ are in order of: $\mathrm{ERP}<\mathrm{BM}<\mathrm{TSP}$. High solubility of $\mathrm{Pb}$ and $\mathrm{P}$ is required for a successful $\mathrm{Pb}$ immobilization for formation of pyromorphite other than low soil $\mathrm{pH}$ and high $\mathrm{Pb} / \mathrm{P}$ ratio (Chrysochoou et al. 2007). Thus, TSP and BM are probably better materials to immobilize $\mathrm{Pb}$ based on assessment made on their solubility.

Dissolution of $\mathrm{Pb}$ and $\mathrm{P}$ amendments, which is enhanced by decreasing $\mathrm{pH}$, is necessary for pyromorphitetype minerals to form. However, it is best to record that materials used, contained significant amount of trace metals particularly Cd. But, its releases in the soil system dictates by its phosphate materials origin and reactivity. The reactivity of the phosphate rock governs the availability of $\mathrm{Cd}$ due to its strong binding properties with phosphorus in the apatite structure. Correspondingly, the origins of $\mathrm{P}$ amendments also dictate its solubility of $\mathrm{Cd}$ in the soil environment, justifying the usage of ERP instead of others type of phosphate rocks.

\section{Lead concentration in 0 . stamineus}

From Table 2, the trace metals detected were in the range of $\mathrm{mg} \mathrm{kg}^{-1}$ of copper, zinc and lead. Higher level of copper and zinc were detected since high amounts of chicken manure was applied. Chicken manure application to agricultural land has been recognized as a major source of metals input to the soils, and with repeated applications will eventually result in elevated concentrations of metals in soil (Bolan et al. 2010). Thus, monitoring of usage of animal manures are needed to ensure they are not over applied and affect food safety. Results demonstrated that the application of $\mathrm{P}$-amendments were able to lower the lead concentration in the plant tissue significantly which potentially indicates their effectiveness. Reduction of lead percentage in comparison to the control ranged from 44.4 to $52.7 \%$ accordingly. Laperche et al. (1997) showed that, in the presence of large quantity of phosphate, lead accumulated in root tissues more than in untreated contaminated soil. The aerial concentration of lead did not provide conclusion to the fate of $\mathrm{Pb}$, which was probably higher in the roots than in aerial parts of $O$. stamineus.
Table 2: Effect of different $P$-amendments application on heavy metals contents in $O$. stamineus aerial plant tissues

\begin{tabular}{llll}
\hline \multirow{2}{*}{ Treatment } & $\mathbf{C u}$ & $\mathbf{Z n}$ & Pb \\
\cline { 2 - 4 } & \multicolumn{3}{c}{$(\mathbf{m g} / \mathbf{k g})$} \\
\hline Control & $27.98 \mathrm{ab}$ & $92.03 \mathrm{a}$ & $3.58 \mathrm{a}$ \\
BM 2 & $18.33 \mathrm{~b}$ & $73.93 \mathrm{a}$ & $1.98 \mathrm{~b}$ \\
BM 4 & $26.85 \mathrm{ab}$ & $85.13 \mathrm{a}$ & $2.20 \mathrm{~b}$ \\
ERP1 & $24.30 \mathrm{ab}$ & $60.88 \mathrm{a}$ & $1.68 \mathrm{~b}$ \\
ERP2 & $22.10 \mathrm{ab}$ & $64.98 \mathrm{a}$ & $1.88 \mathrm{~b}$ \\
TSP2 & $37.68 \mathrm{a}$ & $83.95 \mathrm{a}$ & $1.73 \mathrm{~b}$ \\
Pr>F & $\mathrm{ns}$ & $\mathrm{ns}$ & $*$ \\
\hline
\end{tabular}

${ }^{*}$ Means in each column, followed by the same letter, are not significantly different according to the Tukey test ( $P>0.05)$

\section{The $O$. stamineus phytoremediator abilities}

The assessed metals as indicated showed that the $O$. stamineus have abilities to take up copper, zinc and lead. Based on the results, the $O$. stamineus was capable of accumulating $\mathrm{Pb}$ concentrations at 1.7 to $3.6 \mathrm{mg} / \mathrm{kg}$, zinc concentrations at 60.9 to $92.0 \mathrm{mg} / \mathrm{kg}$ and copper concentrations at 18.3 to $37.7 \mathrm{mg} / \mathrm{kg}$. Previous study by Manan et al., (2015) indicated that $O$. stamineus roots were more significant in accumulating $\mathrm{Zn}, \mathrm{Cu}$ and $\mathrm{Pb}$ whilst $\mathrm{Zn}$ and $\mathrm{Cu}$ metals positively correlated in the leaves and stems of Orthosiphon stamineus ( $\mathrm{r}=0.99$ and 0.80 , respectively). Reviewing on apatite application on $\mathrm{Pb}, \mathrm{Zn}$ and $\mathrm{Cu}$ concentration in plant tissues, only 2 t/ha of TSP application showed higher $\mathrm{Cu}$ concentration than control. Ma et al., (1994) showed that $\mathrm{Cu}$ and $\mathrm{Zn}$ could also be sorbed by apatite, but less effective than lead. The mechanism of immobilization for these metals was not identified, but it can be adsorption or precipitation (Xu et al., 1994). The effectiveness of $\mathrm{P}$ amendments decreases in multielement contaminated soils. The competitive metal sorption was observed to reduce the binding capacity of hydroxyapatite, as example, $\mathrm{Pb}, \mathrm{Cu}$ and $\mathrm{Zn}$ when simultaneously present in soil solution (Corami et al., 2007; Cao et al., 2004).

\section{Plant biomass and nutrients uptake}

Aerial dry weights of $O$. stamineus were in a range of $17.60 \mathrm{~g}$ to $28.34 \mathrm{~g}$ after harvest. However, there is no significant difference in the biomass yield between different rates and types of P-amendments used (Table 3). The dry weights of the aerial, roots and aerial roots ratio of $O$. stamineus are not significantly different between treatments. Similarly, the aerial roots ratio indicated no significant results between the treatments as well as for carbon, nitrogen, phosphorus, potassium, calcium and magnesium in plant tissues (Table 3 and 4). However, addition of $10 \mathrm{t} / \mathrm{ha}$ of chicken manure is more than 
sufficient to meet the nutrient requirements of the crops, albeit considered impractical and costly. Study by Vimala et al. (2002), indicated that the nutrients uptake of $O$. stamineus grown on sandy soil with $30 \mathrm{t} / \mathrm{ha}$ application of chicken manure were as follows; nitrogen at $4.03 \%$, phosphorus at $0.92 \%$, potassium at $2.50 \%$, calcium at $2.07 \%$ and magnesium is about $0.93 \%$ to $1.02 \%$. In their study, sandy soil was used, thus the high amounts applied are justifiable due to consideration of nutrients leaching. Based on evaluation, there are no symptom of deficiency occurring during the growth trial. In this sense, $10 \mathrm{t} / \mathrm{ha}$ of chicken manure should be sufficient for the crops to grow well on mineral soils.

\section{Lead phase association}

Soil fraction has been conducted to evaluate the effectiveness of $\mathrm{P}$-amendments in reducing available $\mathrm{Pb}$ for plants uptake (Figure 1). The soil has undergone 5 steps of fraction into a more stable complex found in residual fraction (Figure 1). An obvious choice of a phosphate reagent to test for lead treatment was commercial fertilizers that contain phosphate, commonly known as TSP (produce by reacting phosphoric acid with phosphate rock) due to its high water solubility.

The chemical precipitation of metals rely on the solubility products of the solids formed, metal sorption involves adsorption, surface precipitation or coprecipitation, and intra-particle diffusion. The rate of solubility of materials also give impact on effectiveness of the treatments. For example, the relative dissolution of phosphate rock in order to immobilize $\mathrm{Pb}$ at its natural $\mathrm{pH}$ 8.7 is low, unlike at lower $\mathrm{pH} 3.7$ whereby $\mathrm{Pb}$ immobilization is instantaneous, forming a pyromorphite minerals (Melamed et al. 2003). The formation of pyromorphite in soil requires dissolution of $\mathrm{Pb}$ and $\mathrm{P}$ amendments, respectively. The rate and effectiveness of the

Table 3: Effect of different $P$-amendments application on biomass of $\boldsymbol{O}$. stamineus produce

\begin{tabular}{llll}
\hline Treatment & Dry aerial weight $(\mathbf{g})$ & Dry roots weight $(\mathbf{g})$ & Aerial roots ratio \\
\hline Control & $19.88 \mathrm{a}$ & $34.03 \mathrm{a}$ & $0.62 \mathrm{a}$ \\
BM 2 & $24.28 \mathrm{a}$ & $33.91 \mathrm{a}$ & $0.80 \mathrm{a}$ \\
BM 4 & $27.36 \mathrm{a}$ & $40.50 \mathrm{a}$ & $1.13 \mathrm{a}$ \\
ERP 1 & $28.34 \mathrm{a}$ & $33.58 \mathrm{a}$ & $1.12 \mathrm{a}$ \\
ERP 2 & $17.60 \mathrm{a}$ & $16.68 \mathrm{a}$ & $1.17 \mathrm{a}$ \\
TSP 2 & $20.79 \mathrm{a}$ & $26.30 \mathrm{a}$ & $0.93 \mathrm{a}$ \\
Pr>F & $\mathrm{ns}$ & $\mathrm{ns}$ & $\mathrm{ns}$ \\
\hline
\end{tabular}

Table 4: Effect of P-amendments application on selected plant nutrients concentration of $O$. stamineus

\begin{tabular}{lllllll}
\hline Treatment & $\mathbf{C}(\boldsymbol{\%})$ & $\mathbf{N}(\boldsymbol{\%})$ & $\mathbf{P}(\boldsymbol{\%})$ & $\mathbf{K}(\boldsymbol{\%})$ & $\mathbf{C a}(\boldsymbol{\%})$ & $\mathbf{M g}(\boldsymbol{\%})$ \\
\hline Control & $41.7 \mathrm{a}$ & $2.1 \mathrm{~b}$ & $0.25 \mathrm{a}$ & $2.93 \mathrm{a}$ & $2.10 \mathrm{a}$ & $0.081 \mathrm{a}$ \\
BM 2 & $41.4 \mathrm{ab}$ & $2.4 \mathrm{ab}$ & $0.29 \mathrm{a}$ & $3.08 \mathrm{a}$ & $2.02 \mathrm{a}$ & $0.081 \mathrm{a}$ \\
BM 4 & $40.4 \mathrm{~b}$ & $3.0 \mathrm{a}$ & $0.28 \mathrm{a}$ & $2.93 \mathrm{a}$ & $2.08 \mathrm{a}$ & $0.082 \mathrm{a}$ \\
ERP 1 & $41.4 \mathrm{ab}$ & $2.2 \mathrm{~b}$ & $0.27 \mathrm{a}$ & $2.93 \mathrm{a}$ & $1.78 \mathrm{a}$ & $0.081 \mathrm{a}$ \\
ERP 2 & $40.7 \mathrm{ab}$ & $2.6 \mathrm{ab}$ & $0.23 \mathrm{a}$ & $2.94 \mathrm{a}$ & $2.08 \mathrm{a}$ & $0.081 \mathrm{a}$ \\
TSP 2 & $41.7 \mathrm{a}$ & $2.2 \mathrm{~b}$ & $0.39 \mathrm{a}$ & $3.23 \mathrm{a}$ & $1.63 \mathrm{a}$ & $0.082 \mathrm{a}$ \\
Pr>F & $\mathrm{ns}$ & $\mathrm{ns}$ & $\mathrm{ns}$ & $\mathrm{ns}$ & $\mathrm{ns}$ & $\mathrm{ns}$ \\
\hline
\end{tabular}

*Means in each column, followed by the same letter, are not significantly different according to the Tukey test $(\mathrm{P}>0.05)$

sequential extraction according to Tessier et al. (1979) right after harvest. In general, the application of P-amendments either using bone meal, Egyptian rock phosphate or triple super phosphate shows a reduction in exchangeable lead fraction and increase in residual fraction. The application of $10 \mathrm{t} / \mathrm{ha}$ of chicken manure added a significant amount of $\mathrm{Pb}$ in the exchangeable fraction. The least percentage of $\mathrm{Pb}$ in exchangeable fraction were in this order; TSP2>ERP2>ERP1>BM4>BM2. These suggested that application of these $\mathrm{P}$-amendments have abilities to stabilize the lead in soil from exchangeable and other
$\mathrm{Pb}$ immobilization fairly depends on solubility of $\mathrm{Pb}$ and $\mathrm{P}$ amendments (Kumpiene et al. 2008).

Study by Brown et al. (2005) indicates phosphatebased salts and phosphoric acid are more soluble and efficient for this purpose in comparison to phosphate rock. It has been suggested that a far more reactive and soluble Psources materials be utilized for immobilizing the $\mathrm{Pb}$. However, application of rapid and soluble P-amendments such as phosphoric acids and salts are potentially postulated to lower the soil $\mathrm{pH}$ and could contribute towards acidification. Even the release of $\mathrm{Pb}$ into soil solution is 


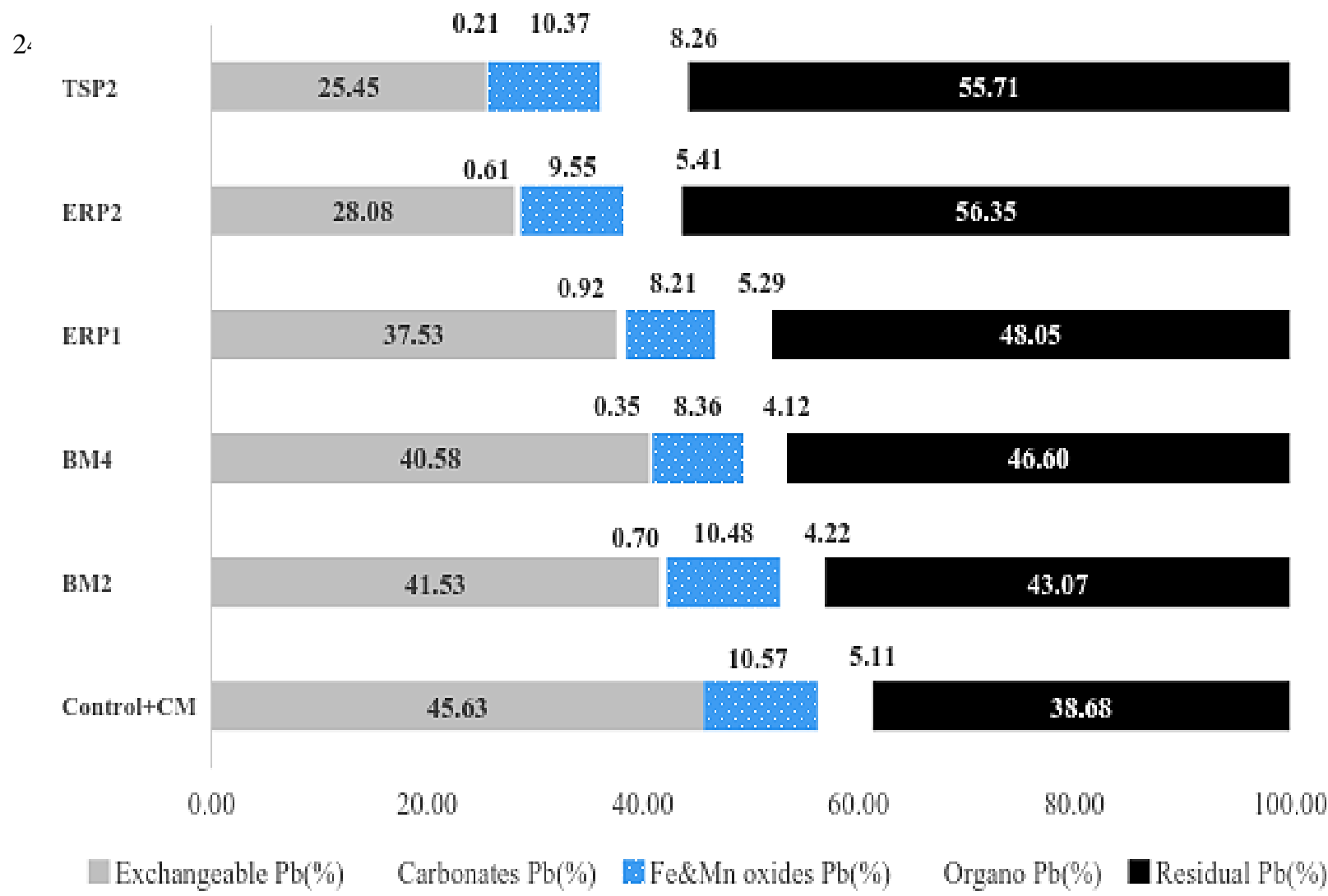

Figure 1: The lead content expressed as percentage in 5 fractions; 1) exchangeable, 2) carbonates, 3) Fe \& Mn oxides, 4) organic matter and 5) residual with application of different $P$-amendments

increased for a better immobilization process to be conducted under low soil $\mathrm{pH}$, such drastic measure should be avoided or with counter measure taken to increase the $\mathrm{pH}$ such as adding liming materials. Moreover, the amounts and the rate of application plays an important role in order for such mechanism to occur effectively. Several study usually expressed the amounts of added material as a percent of amendment added to soil (weight ratio), as a concentration of $\mathrm{P}$ per $\mathrm{kg}$ soil or $\mathrm{t}$ per ha, or as a molar ratio $\mathrm{P} / \mathrm{Pb}$. Despite that, some doubts about stabilization of $\mathrm{Pb}$ by phosphorus arises as there is potential for formation of other minerals than pyromorphite (Porter et al. 2004). Thus, high rate of application is suggested with amounts of $\mathrm{P}$ in soil needs to be increased to the levels that are 20 times the normal P concentration in soil (Porter et al. 2004). This is not cost effective and unsuitable for this type of research, since the P-sources act fairly as amendments.

\section{Fractionation of lead in soil}

Based on Table 5, fractions of lead in the receiving soil was inter-changing between exchangeable $\mathrm{Pb}$ and residual $\mathrm{Pb}$ fractions. The application of $10 \mathrm{t} / \mathrm{ha}$ of chicken manure was kept constant for all of the treatments. As shown in control treatment, the lead concentration was higher at exchangeable and Fe\&Mn oxides fraction. This indicates that the lead was primarily release from exchangeable fractions and transform into the residual fraction. In general, most of apatite applications were able to reduce the exchangeable fraction bound $\mathrm{Pb}$ and subsequently stabilized it into a more stable form in minerals. The mechanisms involved in $\mathrm{P}$-induced $\mathrm{Pb}$ immobilization include ionic exchange and chemical precipitation. Several studies suggest that a potential retention mechanism of hydroxyapatite for $\mathrm{Pb}$ (Suzuki et al. 1981) is ionic exchange with Ca. However, Ma et al. (1994) demonstrated that $\mathrm{Pb}$ reacts with hydroxyapatite $[\mathrm{Ca} 5(\mathrm{PO} 4) 3 \mathrm{OH}]$ in solution, forming stable pyromorphite-type minerals [Pb5(PO4)3X; $X=\mathrm{F}, \mathrm{Cl}, \mathrm{Br}$ and $\mathrm{OH}]$, suggesting dissolution of hydroxyapatite followed by precipitation of pyromorphite as the primary mechanism. The solubility of $\mathrm{P}$ amendments dictates their effectiveness in $\mathrm{Pb}$ immobilization process. Even then, pyromorphite can only be detected in the soil system when present at a concentration of greater than $5 \%$ (Ma et al. 1994).

\section{Transfer factors of heavy metals}

Table 6 indicates the transfer factors of lead when applied with different rates and type of P-amendments. Soil to plant transfer of heavy metals is the major path way of human exposure to metal contamination. Based on Table 3, 
Table 5: Effect of P-amendments on lead concentrations in different fractions of the soil

\begin{tabular}{lccccc}
\hline Treatment & $\begin{array}{c}\text { Exchangeable } \\
\text { Pb }(\mathbf{m g} / \mathbf{k g})\end{array}$ & $\begin{array}{c}\text { Carbonates } \\
\text { Pb }(\mathbf{m g} / \mathbf{k g})\end{array}$ & $\begin{array}{c}\text { Fe \& Mn Oxides Pb } \\
(\mathbf{m g} / \mathbf{k g})\end{array}$ & $\begin{array}{c}\text { Organic } \\
\text { matters Pb }(\mathbf{m g} / \mathbf{k g})\end{array}$ & $\begin{array}{c}\text { Residual } \\
(\mathbf{m g} / \mathbf{k g})\end{array}$ \\
\hline Control & $9.90 \mathrm{a}$ & - & $2.27 \mathrm{a}$ & $1.11 \mathrm{~b}$ & $8.44 \mathrm{a}$ \\
BM 2 & $8.75 \mathrm{ab}$ & $0.14 \mathrm{a}$ & $2.20 \mathrm{a}$ & $0.88 \mathrm{~b}$ & $9.05 \mathrm{a}$ \\
BM 4 & $8.64 \mathrm{ab}$ & $0.08 \mathrm{a}$ & $1.78 \mathrm{~b}$ & $0.88 \mathrm{~b}$ & $1.11 \mathrm{~b}$ \\
ERP 1 & $7.89 \mathrm{~b}$ & $0.20 \mathrm{a}$ & $1.73 \mathrm{~b}$ & $1.09 \mathrm{~b}$ & $10.24 \mathrm{a}$ \\
ERP 2 & $5.62 \mathrm{c}$ & $0.12 \mathrm{a}$ & $1.87 \mathrm{~b}$ & $1.42 \mathrm{a}$ & $11.31 \mathrm{a}$ \\
TSP 2 & $4.45 \mathrm{c}$ & $0.05 \mathrm{a}$ & $1.84 \mathrm{~b}$ & $*$ & $\mathrm{~ns}$ \\
Pr>F & $* * *$ & $\mathrm{~ns}$ & $*$ & $\mathrm{a}$ & \\
\hline
\end{tabular}

*Means in each column, followed by the same letter, are not significantly different according to the Tukey test (P>0.05)

Table 7: Pearson correlation coefficients between Pb uptakes and soil fractions $(\mathbf{n}=24)$

\begin{tabular}{|c|c|c|c|c|c|}
\hline & \multicolumn{5}{|c|}{ Pearson Correlation Coefficients, $N=24$} \\
\hline & \multicolumn{5}{|c|}{ Prob $>|\mathbf{r}|$ under H0: Rho=0 } \\
\hline & Exchangeable Pb & Organic matters $\mathbf{P b}$ & Carbonates $\mathbf{P b}$ & Fe\&Mn Oxides Pb & Residual \\
\hline Pb uptake & $0.42^{*}$ & $0.024^{\mathrm{ns}}$ & $-0.22^{\mathrm{ns}}$ & $0.11^{\mathrm{ns}}$ & $-0.40^{\mathrm{ns}}$ \\
\hline Available P & $-0.40^{\mathrm{ns}}$ & $-0.26^{\mathrm{ns}}$ & $0.16^{\mathrm{ns}}$ & $0.03^{\mathrm{ns}}$ & $0.08^{\mathrm{ns}}$ \\
\hline Soil pH & $-0.08 \mathrm{~ns}$ & $0.06 \mathrm{~ns}$ & $0.38 \mathrm{~ns}$ & $0.06 \mathrm{~ns}$ & $-0.27 n s$ \\
\hline
\end{tabular}

Remarks: ns-not sig., $* \mathrm{P}<0.05$

$\mathrm{Pb}$ showed a reduction in $\mathrm{TF}$ after $\mathrm{P}$ application. Even statistically these values were not significant. The best application to lower $\mathrm{Pb}$ transfer factor accordingly are as follows: BM2>ERP1=TSP2=BM4=ERP2>control. Manan et al. (2015) indicates translocation factors for $O$. stamineus grown on contaminated soil obtained from industrial land is 0.12. Similarly, the value obtained in this study were between $0.10-0.22 \mathrm{TF}$, which 0.22 shows in control treatment with addition of $10 \mathrm{t} / \mathrm{ha}$ of chicken manure. Thus, it can be concluded that $O$. stamineus have ability to take up $\mathrm{Pb}$ at certain amounts, even though not qualifying as a hyperaccumulator species.

Table 6: Effect of different application of Pamendments on TF coefficients or transfer of lead to plants

\begin{tabular}{ll}
\hline Treatment & TF Pb \\
\hline Control & $0.22 \mathrm{a}$ \\
BM 2 & $0.07 \mathrm{~b}$ \\
BM 4 & $0.14 \mathrm{ab}$ \\
ERP 1 & $0.10 \mathrm{ab}$ \\
ERP 2 & $0.15 \mathrm{ab}$ \\
TSP 2 & $0.10 \mathrm{ab}$ \\
Pr>F & ns \\
\hline
\end{tabular}

*Means in each column, followed by the same letter, are not significantly different according to the Tukey test $(\mathrm{P}>0.05)$

\section{Correlation coefficient between $\mathrm{Pb}$ uptake with $\mathrm{Pb}$ in soil fractions}

Table 7 indicates the correlation of $\mathrm{Pb}$ uptake, available $\mathrm{P}$ and soil $\mathrm{pH}$ against $\mathrm{Pb}$ in all soil fractions. Based on
Table 5, shows that the $\mathrm{Pb}$ uptake in aerial plants have a positive significant correlation with exchangeable $\mathrm{Pb}$ fraction of soil $(\mathrm{R}$ value $=0.42)$. This means that the exchangeable fraction particularly contributes for lead uptake in $O$. stamineus plant tissues. The total concentrations of heavy metals in soil do not indicate the amounts that are available for plant uptake (Srikanth and Reddy 1991). Measurements using selected pools via fractionation study enables us to assess the fractions which are responsible to replenish the heavy metals in the soil solution for plant uptake. Based on Table 4, the significant correlation between exchangeable $\mathrm{Pb}$ in soil and plant uptake for $\mathrm{Pb}$ reaffirmed this hypothesis.

\section{Conclusion}

Based on this study, O. stamineus have abilities to take up certain amounts of copper, zinc and lead. Applications of P-amendments tested shows effectiveness of TSP in reducing lead in soils. The best treatments are as follows; TSP $2>$ ERP $2=\mathrm{ERP} 1>\mathrm{BM} 4=\mathrm{BM} 2>$ control. These treatments were recorded able to stabilize the $\mathrm{Pb}$ as per indicated in the percentage reduction in phytoavailable form pools into a more stable form of complex. The reduction of $\mathrm{Pb}$ concentrations in aerial plant tissues also were portrayed as follows; TSP2 $=\mathrm{ERP} 1>\mathrm{ERP} 2>\mathrm{BM} 2>$ BM4 even though the concentrations are not significantly different. There is no significant difference in TF value for $\mathrm{Pb}$ upon application of apatite, but the reduction of lead TF across P-amendments indicate their effectiveness. Correlation analysis indicates that the source of available 
$\mathrm{Pb}$ for plant uptakes was derived from the exchangeable fraction.

\section{Acknowledgement}

This work was financially supported by Putra IPB Grant (Sub-Project)/IPM/IPS-Urban Agriculture Project: Quality Control on Heavy Metals and Organic Contaminants of Urban Agriculture Produce.

\section{References}

Abdu, Arifin, Najihah Aderis, Hazandy Abdul Hamid, Nik Ab Majid, Nik Muhamad, Shamsuddin Jusop, Karam Singh, Daljit Singh, and Khairulmazmi Ahmad. "Using orthosiphon stamineus B. for Phytoremediation of heavy metals in soils amended with sewage sludge." American Journal of Applied Sciences 8, no. 4 (2011): 323-331.

Bolan, Nanthi S., A. A. Szogi, Thammared Chuasavathi, Balaji Seshadri, M. J. Rothrock, and P. Panneerselvam. "Uses and management of poultry litter." World's Poultry Science Journal 66, no. 04 (2010): 673-698.

Businelli, D., L. Massaccesi, D. Said-Pullicino, and G. Gigliotti. "Long-term distribution, mobility and plant availability of compost-derived heavy metals in a landfill covering soil." Science of the Total Environment 407, no. 4 (2009): 1426-1435.

Brown, Sally, Barbara Christensen, Enzo Lombi, Mike McLaughlin, Steve McGrath, Jan Colpaert, and Jaco Vangronsveld. "An inter-laboratory study to test the ability of amendments to reduce the availability of $\mathrm{Cd}$, $\mathrm{Pb}$, and $\mathrm{Zn}$ in situ." Environmental Pollution 138, no. 1 (2005): 34-45.

Cotter-Howells, J., and S. Caporn. "Remediation of contaminated land by formation of heavy metal phosphates." Applied Geochemistry 11, no. 1 (1996): 335-342.

Cao, Xinde, Lena Q. Ma, Dean R. Rhue, and Chip S. Appel. "Mechanisms of lead, copper, and zinc retention by phosphate rock." Environmental pollution 131, no. 3 (2004): 435-444.

Chrysochoou, Maria, Dimitris Dermatas, and Dennis G. Grubb. "Phosphate application to firing range soils for $\mathrm{Pb}$ immobilization: the unclear role of phosphate." Journal of Hazardous Materials 144, no. 1 (2007): 114.

Corami, Alessia, Silvano Mignardi, and Vincenzo Ferrini. "Copper and zinc decontamination from single-and binary-metal solutions using hydroxyapatite." Journal of Hazardous Materials 146, no. 1 (2007): 164-170.

Hettiarachchi, Ganga M., Gary M. Pierzynski, and Michel D. Ransom. "In situ stabilization of soil lead using phosphorus and manganese oxide." Environmental Science \& Technology 34, no. 21 (2000): 4614-4619.

Kumpiene, Jurate, Anders Lagerkvist, and Christian Maurice. "Stabilization of $\mathrm{As}, \mathrm{Cr}, \mathrm{Cu}, \mathrm{Pb}$ and $\mathrm{Zn}$ in soil using amendments-a review." Waste management 28, no. 1 (2008): 215-225.

Leroy, Ben LMM, Lydia Bommele, Dirk Reheul, Maurice Moens, and Stefaan De Neve. "The application of vegetable, fruit and garden waste (VFG) compost in addition to cattle slurry in a silage maize monoculture: Effects on soil fauna and yield." European Journal of Soil Biology 43, no. 2 (2007): 91-100.

Laperche, Valérie, Terry J. Logan, Pranitha Gaddam, and Samuel J. Traina. "Effect of apatite amendments on plant uptake of lead from contaminated soil." Environmental Science \& Technology 31, no. 10 (1997): 2745-2753.

Lestan, Domen, Chun-ling Luo, and Xiang-dong Li. "The use of chelating agents in the remediation of metalcontaminated soils: a review." Environmental pollution 153, no. 1 (2008): 3-13.

Ma, Qi Ying, Samuel J. Traina, Terry J. Logan, and James A. Ryan. "Effects of aqueous $\mathrm{Al}, \mathrm{Cd}, \mathrm{Cu}, \mathrm{Fe}$ (II), Ni, and $\mathrm{Zn}$ on $\mathrm{Pb}$ immobilization by hydroxyapatite." Environmental Science \& Technology 28, no. 7 (1994): 1219-1228.

McGrath, Stephen P., and Caroline H. Cunliffe. "A simplified method for the extraction of the metals Fe, $\mathrm{Zn}, \mathrm{Cu}, \mathrm{Ni}, \mathrm{Cd}, \mathrm{Pb}, \mathrm{Cr}, \mathrm{Co}$ and $\mathrm{Mn}$ from soils and sewage sludges." Journal of the Science of Food and Agriculture 36, no. 9 (1985): 794-798.

Manan, Fazilah Abd, Tsun-Thai Chai, Azman Abd Samad, and Dayangku Dalilah Mamat. "Evaluation of the Phytoremediation Potential of Two Medicinal Plants." Sains Malaysiana 44, no. 4 (2015): 503-509.

Manan, Fazilah Abd, Wee-Han Chia, Nor Farahani Ali Othman, Dayangku Dalilah Mamat, Chun-Shiong Chong, Azman Abd Samad, and Tsun-Thai Chai. "Physical and antioxidative responses of Orthosiphon stamineus towards various copper and lead concentrations." Chemical Speciation \& Bioavailability 27, no. 3 (2015): 106-111.

Melamed, Ricardo, Xinde Cao, Ming Chen, and Lena Q. Ma. "Field assessment of lead immobilization in a contaminated soil after phosphate application." Science of the Total Environment 305, no. 1 (2003): 117-127.

Pallavi, Sharma, and Sh D. Rama. "Lead toxicity in plants." Braz J Plant Physiol 17 (2005): 35-52.

Porter, Spencer K., Kirk G. Scheckel, Christopher A. Impellitteri, and James A. Ryan. "Toxic metals in the environment: thermodynamic considerations for possible immobilization strategies for $\mathrm{Pb}, \mathrm{Cd}, \mathrm{As}$, and 
Hg." Critical reviews in environmental science and technology 34, no. 6 (2004): 495-604.

Soltan, M. E., E. M. Fawzy, and M. N. Rashed. "Assessment on the degree of immobilization of heavy metals in contaminated urban soils by selected phosphate rocks of different particle sizes." Malaysian Journal of soil science 16 (2012): 103-120.

Suzuki, Takashi, Toshiaki Hatsushika, and Yasumasa Hayakawa. "Synthetic hydroxyapatites employed as inorganic cation-exchangers." Journal of the Chemical Society, Faraday Transactions 1: Physical Chemistry in Condensed Phases 77, no. 5 (1981): 1059-1062.

Tessier, Andre, Pg GC Campbell, and M. Bisson. "Sequential extraction procedure for the speciation of particulate trace metals." Analytical chemistry 51, no. 7 (1979): 844-851.

Srikanth, R., and S. Raja Papi Reddy. "Lead, cadmium and chromium levels in vegetables grown in urban sewage sludge-Hyderabad, India." Food chemistry 40, no. 2 (1991): 229-234.
Vangronsveld, Jaco, F. Van Assche, and Herman Clijsters. "Reclamation of a bare industrial area contaminated by non-ferrous metals: in situ metal immobilization and revegetation." Environmental Pollution 87, no. 1 (1995): 51-59.

Vimala, P., Mohamed Senawi, M. T., Abdul Ghani, I., Ahmad Shokri, O., YuShyun, C., Mohtar, M. and Yunos, N. M. (2002). Nutrient and heavy metal concentrations, their uptake and distribution in hempedu bumi (Andrographis paniculata) and misai kucing (Orthosiphon stamineus) grown under rubber trees. In Towards modernisation of research and technology in herbal industries. Proceedings of the Seminar on Medicinal and Aromatic Plants, 24-25 July 2001. (pp. 246-253). Forest Research Institute Malaysia (FRIM).

$\mathrm{Xu}$, Yuping, Franklin W. Schwartz, and Samuel J. Traina. "Sorption of $\mathrm{Zn}^{2+}$ and $\mathrm{Cd}^{2+}$ on hydroxyapatite surfaces." Environmental Science \& Technology 28, no. 8 (1994): 1472-1480. 